\title{
ECOLOGICAL, COENOTIC AND CHOROLOGICAL FEATURES OF SYNANTHROPIC SPECIES OF THE GENUS LINUM IN THE FLORA OF UKRAINE
}

Ke y w o rds: Linum, synanthropic species, ecology, coenology, chorology, flora, Ukraine

\begin{abstract}
Results of research and eco-coenotic and chorological features of synanthropic species of the genus Linum in the flora of Ukraine: L. trigynum, L. bienne (hemiapophytes), L. nodiflorum, L. corymbulosum (eventapophytes), L. usitatissimum (ergasiophyte). These species are characterized by wide ecological amplitudes; by their relation to soil humidity most species are hemistenotopic submesophytes, to soil humidity variance - hemieurytopic hemihydrocontrastophiles, to soil acidity - hemistenotopic neutrophiles, and to soil aeration stenotopic subaerophiles. In relation to the general salt regime of soil, hemistenotopic eutrophic species predominate; to the carbonate content in soil - hemistenotopic acarbonatophiles, to the assimilable nitrogen content in the soil - hemistenotopic heminitrophiles. The leading coenotic group is asectators (not dominants nor subdominants) confined mainly to disturbed ecotopes in mixed segetal-and-ruderal communities. The studied species belong to the Mediterranean geoelement type that includes Eastern Mediterranean (L. bienne, L. corymbulosum, L. nodiflorum) and Mediterranean (L. trigynum) geoelements.
\end{abstract}

According to various authors, the genus Linum L. (Linaceae) contains approximately 200 species [7, 9, 18, $21,23,26,28,29]$. In Ukraine this genus is represented by 23 species [12]; most of them are native and usually non-synanthropic, except five species. Of these five taxa, four species are considered apophytes [13, 14, 27] (L. trigynum and L. bienne - hemiapophytes, L. nodiflorum i L. corymbulosum - eventapophytes [14]), and one species (L. usitatissimum, of Mediterranean or Asian origin) belongs to the alien faction of our flora and is considered an ergasiophyte occasionally escaping from cultivation.

\section{Material and Methods}

Ecological characteristics of synanthropic species of the genus are given according to the synphytoindication method [5] and ecological scales used in the Ecoflora of Ukraine [10], with additions by Ya.P. Didukh [20]. Coenotic affinities of species are based on analyses of authors' phytosociological relevés and additional relevés from the phytocoenotic database of the Geobotany and

(C) O.M. OPTASYUK, I.A. KOROTCHENKO, 2014
Ecology Department of the M.G. Kholodny Institute of Botany, National Academy of Sciences of Ukraine, according to the J. Braun-Blanquet classification [19] and the analysis of available literature [16, 22, 24]. Coenotic ranges of taxa are recognized according to the Ecoflora of Ukraine [10]. Distribution of species over the types of coenoses follows A.L. Belgard [1].

The geographical analysis of synanthropic species of Linum in the flora of Ukraine was performed following Yu.D. Kleopov's classification of geographical elements [11]. Original schematic maps of species distribution in Ukraine were composed using the dot method, based on critical evaluation of materials from Ukrainian and some other herbaria ( $K W, K W H A, L W K S, L W S, Y A L T$, $D N Z, C W U, K W U, O D U, L W, U U, C H E R, S I M F$, $K H E R ; L E, B P, K R A, K R A M)$, as well as on collections and observations during expeditions in 2002-2011, and on critical analysis of relevant plant geography literature.

\section{Results}

Among Linum species occurring in the flora of Ukraine, five are synanthropic, growing on fallow lands in abandoned vineyards, gardens, roadsides, fields, weedy places, and as weeds in agrophytocenoses. Synanthropic Linum species are generally characterized by rather wide ecological amplitudes; most of them generally show no clear affinity to the chemical composition and structure of soil.

Ecological analysis of the species studied showed that in relation to soil humidity $(H d)$ all of them are hemistenotopic submesophytes - plants of moderately dry forest-meadow ecotopes with moderate soaking of the root layer of soil by rainfall and meltwater, with the only exception of $L$. corymbulosum, which belongs to subxerophytes. In relation to humidity $(f H)$, the studied species are hemieurytopic hemihydrocontrastophiles, i.e. plants of moderately dry forest-meadow and meadow-steppe ecotopes of uneven moistening of the root layer of soil with moderate or slight soaking by 
rainfall and meltwater. In relation to soil acidity $(R c)$, they are hemistenotopic neutrophiles, plants of neutral soils. In relation to soil aeration $(A e)$, they can be characterized as stenotopic subaerophiles, or plants of significantly aerated soils containing crushed rock and sand, growing under low to moderate soaking of the root layer of soil by rainfall and meltwater (Table).

In relation to the general salt regime of soil $(S l)$, L. nodiflorum and L. usitatissimum are hemistenotopic eutrophic species; L. bienne is a hemieurytopic eutrophe growing on rich, well provided with salts chernozems in the absence of salinity, while L. trigynum should be considered a hemistenotopic mesotrophe. Linum corymbulosum should be considered a hemistenotopic semieutrophe.

In relation to the carbonate content in soil $(\mathrm{Ca})$, L. usitatissimum is eurytopic acarbonatophile, L. trigynum is hemistenotopic acarbonatophile (plants of neutral ecotopes that tolerate minor carbonate contents in the soil); and L. bienne and L. corymbulosum are hemistenotopic hemicarbonatophiles growing on soils enriched by carbonates. L. nodiflorum is a hemistenotopic carbonatophile; it grows in soils rich in carbonates. In relation to the assimilable nitrogen content in the soil (Nt), most species (L. bienne, L. corymbulosum, L. usitatissimum) are hemistenotopic, but $L$. nodiflorum is a hemieurytopic heminitrophile growing on soils with relatively low levels of mineral nitrogen, while L. trigynum is classified as a hemieurytopic subanitrophile growing on soils with very low levels of mineral nitrogen $[25,27]$.

Coenotically the studied species are assectators not playing significant roles in phytocoenoses. Linum corymbulosum and $L$. nodiflorum are confined to the Mediterranean-type annual savannoid communities on disturbed soils (Cl. Thero-Brachypodietea Br.-B1. 1947, Ord. Thero-Brachypodietalia Br.-Bl. 1936, All. Diantho humilis-Velesion Korzh. 1990). These communities are developed on clayey soils formed as a result of weathering of calcareous rocks; $L$. corymbulosum sometimes even occurs on acarbonaceous or hemicarbonaceous shales [15]. Linum corymbulosum grows in communities of Cl. Quercetea pubescenti-petraeae Jakucs (1960) 1961, Ord. Orno-Cotinetalia Jakucs (1960) 1961, All. Jasmino-Juniperion excelsae Didukh, Vakarenko et Shelyag 1986 ex Didukh 1996; it prefers Submediterranean deciduous and coniferous forests and woods of the lower vegetation belts of the Crimean Mountains.

Ecological characteristics of synanthropic species of Linum in the flora of Ukraine

\begin{tabular}{|c|c|c|c|c|c|c|c|}
\hline \multirow[b]{2}{*}{ Types } & \multicolumn{7}{|c|}{ EDAPHОTОРЕ } \\
\hline & $\begin{array}{l}\text { soil humidity } \\
\text { (Hd) }\end{array}$ & $\begin{array}{c}\text { variability of } \\
\text { humidity } \\
(f H)\end{array}$ & $\begin{array}{l}\text { acid soil profile } \\
\qquad(R c)\end{array}$ & $\begin{array}{c}\text { soil salinity regime } \\
(S I)\end{array}$ & $\begin{array}{c}\text { carbonate content } \\
\text { in soil } \\
(\mathrm{Ca})\end{array}$ & $\begin{array}{c}\text { nitrogen content } \\
\text { in soil } \\
(N t)\end{array}$ & $\begin{array}{l}\text { soil aeration } \\
\quad(A e)\end{array}$ \\
\hline 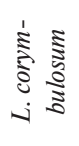 & $\begin{array}{l}\text { hemistenotopic } \\
\text { subkserophyte } \\
\quad(5-11)\end{array}$ & $\begin{array}{l}\text { hemieurytopic } \\
\text { hemihydro- } \\
\text { contrasophile } \\
\quad(4-9)\end{array}$ & $\begin{array}{l}\text { hemistenotopic } \\
\text { neutrophile } \\
\quad(7-12)\end{array}$ & $\begin{array}{l}\text { hemistenotopic } \\
\text { semieutrophe } \\
\quad(5-11)\end{array}$ & $\begin{array}{l}\text { hemistenotopic } \\
\text { hemicarbo- } \\
\text { natophile } \\
(6-11)\end{array}$ & $\begin{array}{l}\text { hemistenotopic } \\
\text { heminitrophile } \\
\qquad(3-6)\end{array}$ & $\begin{array}{l}\text { stenotopic } \\
\text { subaerophile } \\
\quad(5-7)\end{array}$ \\
\hline 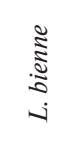 & $\begin{array}{l}\text { hemistenotopic } \\
\text { submesophyte } \\
\qquad(5-13)\end{array}$ & $\begin{array}{l}\text { hemieurytopic } \\
\text { hemihydro- } \\
\text { contrasophile } \\
\quad(4-9)\end{array}$ & $\begin{array}{l}\text { hemistenotopic } \\
\text { neutrophile } \\
\quad(7-12)\end{array}$ & $\begin{array}{l}\text { hemieurytopic } \\
\text { eutrophe } \\
(5-15)\end{array}$ & $\begin{array}{l}\text { hemistenotopic } \\
\text { hemicarbo- } \\
\text { natophile } \\
(7-12)\end{array}$ & $\begin{array}{l}\text { hemistenotopic } \\
\text { heminitrophile } \\
\qquad(3-6)\end{array}$ & $\begin{array}{l}\text { stenotopic } \\
\text { subaerophile } \\
\quad(5-7)\end{array}$ \\
\hline 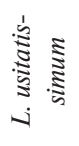 & $\begin{array}{l}\text { hemistenotopic } \\
\text { submesophyte } \\
\qquad(5-13)\end{array}$ & $\begin{array}{l}\text { hemieurytopic } \\
\text { hemihydro- } \\
\text { contrasophile } \\
(4-9)\end{array}$ & $\begin{array}{l}\text { hemistenotopic } \\
\text { neutrophile } \\
\quad(7-11)\end{array}$ & $\begin{array}{l}\text { hemistenotopic } \\
\text { eutrophe } \\
\quad(6-12)\end{array}$ & $\begin{array}{l}\text { eurytopic acarbo- } \\
\text { natophile } \\
(3-12)\end{array}$ & $\begin{array}{l}\text { hemistenotopic } \\
\text { heminitrophile } \\
\qquad(3-6)\end{array}$ & $\begin{array}{l}\text { stenotopic } \\
\text { subaerophile } \\
\quad(5-7)\end{array}$ \\
\hline 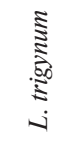 & $\begin{array}{l}\text { hemistenotopic } \\
\text { submesophyte } \\
\qquad(5-13)\end{array}$ & $\begin{array}{l}\text { hemieurytopic } \\
\text { hemihydro- } \\
\text { contrasophile } \\
\text { (4-9) }\end{array}$ & $\begin{array}{l}\text { hemistenotopic } \\
\text { neutrophile } \\
\quad(7-12)\end{array}$ & $\begin{array}{l}\text { hemistenotopic } \\
\text { mesotrophe } \\
(3-9)\end{array}$ & $\begin{array}{l}\text { hemistenotopic } \\
\text { acarbonatophile } \\
\qquad(5-10)\end{array}$ & $\begin{array}{l}\text { hemieurytopic } \\
\text { subanitrophile } \\
\qquad(1-6)\end{array}$ & $\begin{array}{l}\text { stenotopic } \\
\text { subaerophile } \\
\quad(5-7)\end{array}$ \\
\hline 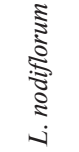 & $\begin{array}{l}\text { hemistenotopic } \\
\text { submesophyte } \\
\quad(5-12)\end{array}$ & $\begin{array}{l}\text { hemieurytopic } \\
\text { hemihydro- } \\
\text { contrasophile } \\
\text { (4-9) }\end{array}$ & $\begin{array}{l}\text { hemistenotopic } \\
\text { neutrophile } \\
\quad(7-12)\end{array}$ & $\begin{array}{l}\text { hemistenotopic } \\
\text { eutrophe } \\
\quad(5-12)\end{array}$ & $\begin{array}{l}\text { hemistenotopic } \\
\text { carbonatophile } \\
\quad(9-12)\end{array}$ & $\begin{array}{l}\text { hemieurytopic } \\
\text { heminitrophile } \\
\qquad(1-8)\end{array}$ & $\begin{array}{l}\text { stenotopic } \\
\text { subaerophile } \\
\quad(5-7)\end{array}$ \\
\hline
\end{tabular}


Linum usitatissimum is an ergasiophyte confined to grassy communities that develop under the excessive influence of the anthropic factor. It is a member of segetal communities in arable and other agricultural lands, occurring on ashen-gray, gray forest soils, and podzolic chernozems of sufficient moisture content (Cl. Secalietea Br.-B1. 1951, Ord. Secalietalia Br.-B1. 1951, All. Chenopodio albi-Descuranion sophiae V. et T. Sl. et Shelyag in V.Sl. 1988, Anthemo ruthenicae-Sisymbrion orientale V. S1. 1988, Caucalidion lappae R. Tx. 1950). It also occurs in communities of pioneer succession stages with annual ruderals, in mixed segetal and ruderal communities at orchard margins, in gardens and vineyards $(\mathrm{Cl}$. Chenopodietea Br.-Bl. 1951 em. Lohm., J. et R. Tx. 1961 ex Matsz., Ord. Eragrostietalia J. Tx. in Poli 1966, All. Eragrostion (R. Tx. 1950) Oberd. 1954), where L. trigynum and L. bienne also occur. The two latter species also occur occasionally in pioneering stages of ruderal communities on dry soils (Cl. Artemisietea vulgaris Lohm., Prsg. et R. Tx. in R. Tx. 1950, Ord. Meliloto-Artemisietalia absinthii Eliaś 1979).

The total range of the genus covers temperate and subtropical areas in the northern and southern hemispheres, including North and South America, large parts of Eurasia, Africa, Australia and New Guinea, and Oceania, with exclaves in Madagascar and the Galapagos Islands [23]. According to Yu.D. Kleopov's classification of geographical elements [11], the studied species belong to the Mediterranean geoelement type that includes Eastern Mediterranean (L. bienne, L. corymbulosum, L. nodiflorum) and Mediterranean (L. trigynum) geoelements, which are actually confined to the Mediterranean coastal regions of the Mediterranean and Black Seas. All species are herbaceous annual or biennial monocarpic plants growing on rocky outcrops and clayey products of weathering of carbonate rocks.

Linum usitatissimum of the nemoral-Mediterranean range type is confined to sandy and loamy soils. The species is cultivated in fields as fiber and oil-bearing crop, often found as escaped near railways and roads. It is cultivated throughout Ukraine and quite often escapes from cultivation; however, at present it shows no clear trend toward naturalization (Figure).

Linum bienne has a Mediterranean-Atlantic range type, being a rare species in Ukraine; it sporadically occurs only in the Crimea [3,9], probably as an alien (adventive) plant growing in dry meadows, pastures, well-lit dry forests, among the bushes, and along the field margins. Specimens of this species are absent in the YALT herbarium, while in the SIMF herbarium we noticed a specimen misidentified as $L$. angustifolium
(«Simferopol reservoir, dry slope, S. Vasilieva, 1989»), which actually belongs to $L$. austriacum; one sample of $L$. angustifolium from the Crimea is stored in $K W$ ( «L. austriacum L. Tauria 1818. Ledebour» № 050660, KW, re-identified by D. M. Dobrochayeva as L. angustifolium).

Linum trigynum is a species of European-Mediterranean-Central Asian distribution. In Ukraine it is a rare species near the northern limit of its range and, according to literature [2, 7, 9], it have been reported for a long time for the flora of Transcarpathia from only two localities near Uzhhorod (outskirts of Kiblyary and Hudlevo villages) and Beregovo. When studying photocopies from the $B P$ herbarium, we found that it is also known from other habitats, some of which are close to the already known localities (Szerednye, Ung., 1900. Magocsy-Dietz S. № 107858 (Serednje village, outskirts of Uzhhorod); com. Bereg. in pascuis pr. Ivangi. 1911/08. A. Mag. № 468628, № 315704 (Ivanivtsi village, outskirts of Berehove), (Magyar Botanikai Lapok, 1911); in locis graminosis solo an argilloso pr. Bubuliska com Berg. - 1912 / VIII - A. Marg. № 107851 (Bobovysche village); Hab. in locis sicci ad pag. Lolo, com Bereg., 1927/07/28 - A. Marg. № 107848, № 441030); Gombás és Ilgócz köst a vágás szélén. Gombás (Hrybivtsi village, which is now included in the Bobovysche village of Mukachevo district). The specimens were collected by two collectors, A. Margittai and S. MagocsyDietz, and are dated from the early $20^{\text {th }}$ century. Collections from these localities are absent in $K W$ and $U U$ herbaria, and there have been no reports about new findings.

Species is confined to rocky screes, slopes and outcrops in foothills, sandy places, grassy slopes, forest edges, meadows, fields, and weedy (ruderal and segetal) places.

Materials from herbaria $K W, Y A L T$, SIMF (collections of O.G. Usacheva, V.M. Kosykh, V.N. Golubev et al.) and literature data provide no confirmation for the presence of $L$. trigynum in the Crimea [3, 4, 6, 8, 17], the available records actually belongs to another morphologically close Crimean species, L. corymbulosum (Figure).

Linum nodiflorum is a species of the MediterraneanMiddle Eastern range type occurring in the Crimean Plains, the Crimean Mountains, and the South Coast of the Crimea. It grows on dry rocky outcrops and screes, clayey soils resulting from weathering of carbonate rocks, grassy slopes, near roads, and along field margins and roadsides. Linum corymbulosum is a species of mainly Mediterranean-Middle Eastern distribution. 

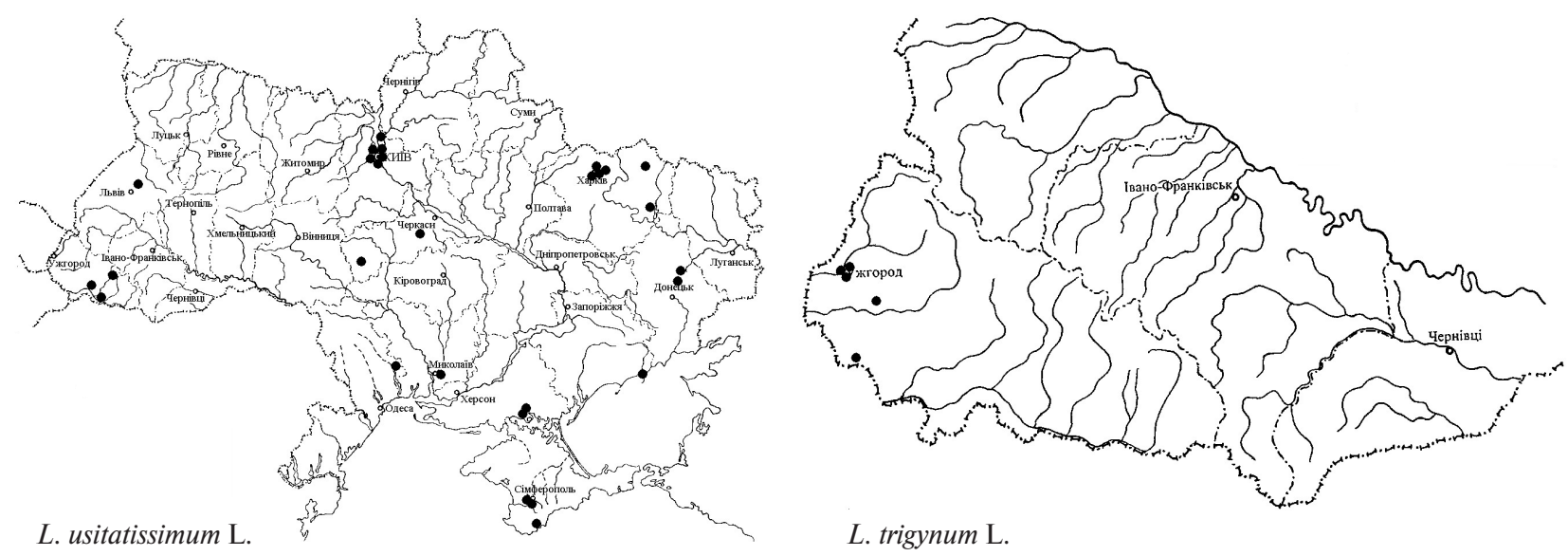

L. trigynum L.
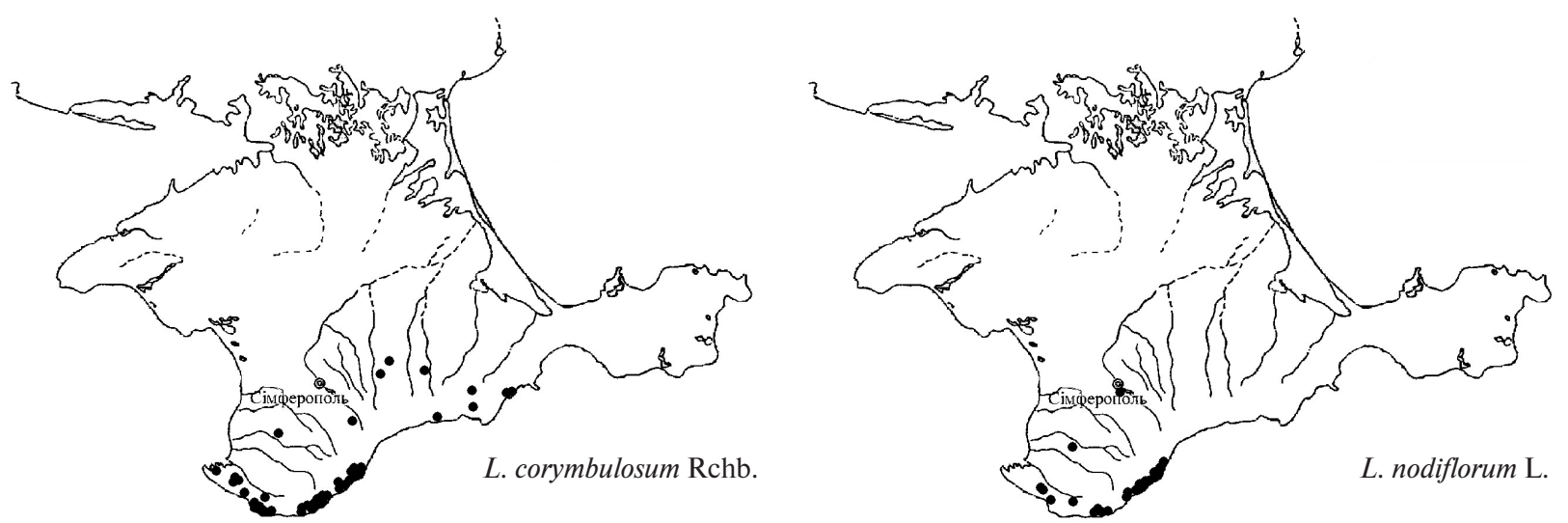

Schematic maps of distribution of synanthropic species of Linum in Ukraine (points indicate the localities of spesies confirmed by herbarium specimens

In Ukraine it is common for in the Crimean Plains, the Crimean Forest-Steppe, the Crimean Mountains, and the South Coast, preferring clay soils formed on carbonate rocks, rarely acarbonaceous or hemicarbonaceous shales, dry rocky slopes, pine and juniper forests, dry meadow slopes, steppes, fields, pastures, and shrubs.

Thus, all synanthropic species of Linum in the flora of Ukraine are herbaceous monocarpic plants characterized by wide ecological amplitudes and restricted mainly to disturbed ecotopes. Most of them are heliophytes, submesophytes, hemihydrocontrasophiles, neutrophiles, eutrophes, hemicarbonatophiles, heminitrophiles, and subaerophiles. They belong to the Mediterranean geoelement type, and act as assectators in plant communities.

\section{REFERENCES}

1. [Belgard A.L.] Бельгард A.Л. Лесная растительность юговостока УССР. - К: Изд.-во Киевск. ун-та, 1950. - 263 с.

2. [Barbarych A.I.] Барбарич A.I. Льонові - Linaceae // Визначник рослин Українських Карпат. - К.: Наук. думка, 1977. - C. $184-185$.
3. [Wulff E.V.] Вульф E.B. Сем. Linaceae (DC.) Dumort. // Культурная флора СССР / Под ред. проф. Е.В. Вульфа. Прядильные. Часть І. - М., Л.: Гос. Изд-во колх. и совх. лит-ры, 1940. - Т. 5. - С. 97-108.

4. [Golubev V.N.] Голубев B.H. Биологическая флора Крыма. 2-е изд. - Ялта: ГНБС, 1996. - 86 с.

5. [Didukh Ya.P., Plyuta P.G.] Дідух Я.П., Плюта П.Г. Фітоіндикація екологічних факторів. - К.: Ін-т ботаніки ім. М.Г. Холодного, 1994. - 280 с.

6. [Dobrochaeva D.M.] Доброчаева Д.M. Семейство Льновые - Linaceae Dum. // Определитель высших растений Украины. - Киев: Наук. думка, 1987. - 545 с.

7. [Dobrozhaeva D.M.] Доброчаєва Д.М. Родина Льонові Linaceae Dum. // Флора УРСР. - К.: Вид-во АН УРСР, 1955. - T. 7. - C. 46-76.

8. [Dubovik O.N.] Дубовик O.Н. Флорогенез Крымско-Новороссийской провинции / Отв. ред. Новосад В.В. Киев: Фитон, 2005. - 180 с.

9. [Egorova T.V.] Егорова T.B. Семейство Linaceae DC. ех S.F. Gray - Льновые // Флора Восточной Европы. СПб.: Мир и Семья-95, 1996. - Т. 9. - С. 346-361.

10. [Ecoflora of Ukraine] Екофлора України / Я.П. Дідух та ін. - К.: Фітосоціоцентр, 2000. - Т. 1. - 284 с.

11. [Kleopov Yu. D.] Клеопов Ю.Д. Анализ флоры широколиственных лесов европейской части СССР. - Киев: Наук. думка, 1990. - 352 с. 
12. [Optasyuk O.M.] Оптасюк O.M. Систематичний огляд роду Linum L. флори України // Укр. ботан. журн. 2007. - 64, № 2 . - C. 229-241.

13. [Optasyuk O.M., Korotchenko I.A.] Оптасюк O.M., Kоротченко I.A. Еколого-ценотична характеристика видів роду Linum L. у флорі України // Укр. ботан. журн. 2011. - 68, № 1. - С. 64-85.

14. [Protopopova V.V.] Протопопова B.B. Синантропная флора Украины и пути ее развития. - Киев: Наук. думка, 1991. - $201 \mathrm{c}$.

15. [Riff L.E.] Рифф Л.E. Флора і рослинність кам'янистих відслонень Гірського Криму: Автореф. дис. ... канд. біол. наук. - Ялта, 2004. -20 с.

16. [Solomakha V.A.] Соломаха B.A. Синтаксономія рослинності України // Укр. фітоцен. зб. - 1996. - Сер. А. Вип. № 4 (5). -119 с.

17. [Chernova N.M.] Чернова H.M. Сем. Linaceae - Льновые // Определитель высших растений Крыма. - Л.: Наука, 1972. - C. 291-293.

18. [Yuzepchuk S.V.] Юзепчук C.B. Семейство Льновые Linaceae Dumort // Флора СССР. - М.; Л., 1949. - T. 14. - C. 84-146.

19. Braun-Blanquet J. Pflanzensoziologie: Grundzuge der Vegetationskunde. - Wien: Springer Verl., 1951. - 631 S.

20. Didukh Ya.P. The ecological scales for the species of Ukrainian flora and their use in synphytoindication. - Kyiv: Phytosociocentre, 2011. - $176 \mathrm{p}$.

21. Hrouda L. Linaceae S.F. Gray. - Lnovité // B. Slavik (ed.). Kvétena Ceske republiky. - Praha, 1997. Vol. 5. - P. 166-178.

22. Matuszkiewicz W. Przewodnik do oznaczania zbiorowisk roślinnych Polski. - Warszawa: PWN, 2001. - 537 s.

23. McDill J., Repplinger M., Simpson B.B., Kadereit J.W. The phylogeny of Linum and Linaceae subfamily Linoideae, with implications for their systematics, biogeography, and evolution of heterostyly // Syst. Bot. - 2009. - 34(2). - P. 386-405.

24. Moravec $J$. et al. Rostlinna společenstva Česke republiky a jejich ohrozeni. - Litoměřice, 1995. - Severočes. Přir., suppl. $-206 \mathrm{p}$.

25. Moroz O.M. A coenotic confinedness of species of the genus Linum L. (Linaceae) of the Ukrainian flora // Plant, fungal and habitats diversity investigation and conservation: IV Balkan Bot. Congress (Sofia, 20-26 June 2006). - Sophia, 2006. - P. 229.

26. Ockendon D.J., Walters S.M. Linum L. // Flora Europaea. - Cambridge: Cambridge Univ. Press, 1968. - Vol. 2. - P. 206-211.

27. Optasyuk O., Korotchenko I. Ecological-coenotic features of the synanthropic species of the genus Linum L. in the flora of Ukraine // IX International Conference Anthropization and Environment of Rural Settlements. Flora and Vegetation. - Kamyanets-Podilskiy \& Boyany, Ukraine, 29 June-01 July 2010. - Program. Proceedings and Excursions. - Kyiv: M.G. Kholodny Institute of Botany, NAS of Ukraine. - 2010. - P. 51-52.

28. Romo A.M. Linaceae// W. Greuter, H. M. Burdet, G. Long. (eds.). Med-Checklist. A critical inventory of vascular plants of the circummediterranean countries. - Geneve, 1989. Vol. 4. - P. 216-226.

29. Winkler H. Linaceae // A. Engler, K. Plantl. Nat. Pflanzenfam. - Leipzig, 1931. - Bd. 19a. - P. 82-130.

Commended for publication by $\quad$ Submitted 12.11.2012 Ya.P. Didukh
O.М. Оптасюк, I.А. Коротченко

Інститут ботаніки імені М.Г. Холодного НАН України, м. Київ

\section{ЕКОЛОГО-ЦЕНОТИЧНІ ТА ХОРОЛОГІЧНІ ОСОБЛИВОСТІ СИНАНТРОПНИХ ВИДІВ РОДУ LINUМ У ФЛОРІ УКРАЇНИ}

Висвітлено результати дослідження еколого-ценотичних і хорологічних особливостей синантропних видів роду $\mathrm{Li}$ num L. у флорі України: L. trigynum, L. bienne (геміапофіти), L. nodiflorum, L. corymbulosum (евентапофіти), L. usitatissimum (ергазіофіт). Види характеризуються широкою екологічною амплітудою; за відношенням до вологості грунту більшість $€$ гемістенотопними субмезофітами, до змінності зволоження грунту - геміевритопними гемігідроконтрастофілами, до кислотного режиму грунту - гемістенотопними нейтрофілами, до аерації грунту - стенотопними субаерофілами. За відношенням до загального сольового режиму грунту переважають гемістенотопні евтрофи, до вмісту карбонатів у грунті - гемістенотопні гемікарбонатофіли, до вмісту засвоюваних форм азоту в грунті - гемістенотопні гемінітрофіли. 3 ценотичного погляду більшість видів $є$ асектаторами; рослини приурочені переважно до порушених екотопів і тяжіють до змішаних сегетально-рудеральних угруповань. Досліджувані види належать до Середземноморського типу геоелемента, що включає східно-середземноморський (L. bienne, L. corymbulosum, L. nodiflorum) та середземноморський геоелементи (L. trigynum).

Ключ о в і слов в: Linum, синантропні види, екологія, ценологія, хорологія, флора України.

О.М. Оптасюк, И.А. Коротченко

Институт ботаники имени Н.Г. Холодного НАН Украины, г. Киев

\section{ЭКОЛОГО-ЦЕНОТИЧЕСКИЕ И ХОРОЛОГИЧЕСКИЕ ОСОБЕННОСТИ СИНАНТРОПНЫХ ВИДОВ РОДА LINUM ВО ФЛОРЕ УКРАИНЫ}

Представлены результаты исследования экологоценотических и хорологических особенностей синантропных видов рода Linum L. во флоре Украины: L. trigynum, L. bienne (гемиапофиты), L. nodiflorum, L. corymbulosum (эвентапофиты), L. usitatissimum (эргазиофит). Виды характеризируются широкой экологической амплитудой; по отношению к влажности почвы - большинство гемистенотопные субмезофиты, к изменению увлажнения почвы - гемиэвритопные гемигидроконтрастофилы, к кислотному режиму - гемистенотопные нейтрофилы, к аэрации почвы - стенотопные субаэрофилы. По отношению к общему солевому режиму почвы преобладают гемистенотопные эвтрофы, к содержанию карбонатов в почве - гемистенотопные гемикарбонатофилы, к содержанию доступных форм азота в почве - гемистенотопные геминитрофилы. В ценотическом отношении преобладают асектаторы, приуроченные преимущественно к нарушенным экотопам в смешанных сегетальнорудеральных сообществах. Исследуемые виды принадлежат к средиземноморскому типу геоэлемента, что включает восточно-средиземноморский (L. bienne, L. corymbulosum, L. nodiflorum) и средиземноморский геоэлементы (L. trigynum).

Ключ е в ы е слов в : Linum, синантропные виды, экология, ценология, хорология, флора Украины. 